\title{
Moscow Interdisciplinary Conference on Autobiography ${ }^{1}$ \\ A Step Forward in the Study of Autobiography in Russia
}

\section{Tom Rollings}

National Research University The Higher School of Economics Moscow Visiting scholar

\section{ABSTRACT}

The conference devoted to "Autobiographical writings in an interdisciplinary research environment: people, texts, practices" was held on 1-2 June 2016 in Moscow at the National Research University The Higher School of Economics (HSE). The conference aimed to promote the study of first-person writings as the product of specific social practices and marked a modest step forward in the study of autobiography in Russia.

Keywords: autobiography, ego-documents, practice, the person

The conference devoted to "Autobiographical writings in an interdisciplinary research environment: people, texts, practices" was held on 1-2 June 2016 in Moscow at the National Research University The Higher School of Economics (HSE). Organised by the Research and Study Group at HSE with the intention of spreading the scholarly study of autobiography as the product of specific social practices, this conference provided evidence of the maturation of research in Russia in the field of autobiography studies, with over 70 papers presented by speakers from Moscow, Saint Petersburg, Kazan, Yekaterinburg, Novosibirsk, Vologda, Tula, Tomsk, Smolensk, Tver, Ufa, Irkurtsk and Samara.

The HSE conference was organised in tandem with a conference at the German Historical Institute on June 3-4 under the title "The Sacral and 
the Secular in Autobiographical Practices of the Modern Period (Eighteenth to Early Twentieth Centuries)". It was therefore fitting that the director of the German Historical Institute, Professor Nikolaus Katzer, welcomed the participants. In his witty speech Professor Katzer noted that the summer holidays would soon be upon us and exhorted us to earn our future rest by intense discussion, including in the event of the German Historical Institute, to which he cordially invited colleagues.

The first-person accounts of clergymen and their families are testament to the importance of autobiography in Russian culture over the past 200 years. Apart from censorship issues in the Soviet period, the study of this corpus of texts was held back by the previous isolation of scholars in the former Soviet Union at a time when scholarship on life-writing in the West was booming in the last decades of the twentieth century. To help fill in the picture of developments in the study of autobiography in recent decades, Rudolf Dekker, founder of the Centre for the Study of Egodocuments and History and joint editor of the "Egodocuments in History" series at Brill, kicked off the conference with a key-note speech that identified long-term developments in autobiography in the Netherlands since $1500 .^{2}$ Throughout his thoughtful and thought-provoking intervention, Dr. Dekker underlined points of overlap between Dutch autobiography and key themes that cropped up in the titles of papers in the conference programme. In particular, the speaker reviewed the study of Anne Frank's diary and recent debates in Holland on how to read egodocuments as evidence of what contemporaries knew about the Holocaust. As conference participants noted, such debates are relevant to the study of the testimony of Soviet period during World War Two, including in the Leningrad blockade.

Tatiana Saburova of Indiana State University began the panel session with an overview of her current research into the "hidden autobiography" of A.V. Tyrkova-Williams (1869-1962) in her biography of Pushkin, which she wrote in exile in Britain after 1917. Tyrkova-Williams had been on the Central Committee of the Cadet party but in exile turned away from politics in order to revive Pushkin's world. Dr. Saburova stressed that her protagonist did not seek merely to preserve the past, but to bring it with her, foreshadowing polemics between the Russian émigré diaspora and official Soviet discourse as to who represented the tradition of Russian culture. Dr. Saburova stressed that the process of writing a biography of Pushkin supported a shift in the biographer's own narrative, with a greater emphasis on her gentry and religious identities, which TyrkovaWilliams had played down in her earlier opposition politics. As a result, Tyrkova-Williams' own self-representation in exile as a liberal conservative professional writer coincided with her portrayal of Pushkin, who was a pioneer in establishing a professional career as a writer. Overall, 
the theme of repentance emerged, whereby the biographer sought to expunge her sense of personal guilt for the collapse of Tsarist Russia by resurrecting this lost world in her scholarship.

Elena Karpenko, a lecturer at the Higher School of Economics and co-ordinator of the HSE research and study group in autobiography, continued the session with a paper that explored the corpus of autobiographical texts included in the five-volume index, published under the editorial guidance of P.A. Zaionchkovskii in the 1970-1980s. ${ }^{3}$ Dr. Karpenko explained that the goal of the study group is to apply to a Russian context the method of research proposed by Gabriele Jancke, viz. in considering autobiographical texts as the products of a set of specific social practices. ${ }^{4}$ Such a research frame, derived from the study of autobiographical texts in German culture, is particularly helpful in the discussion group's regular seminars on eighteenth-century first-person testimony due to the influence of German intellectual culture in Russia following Peter the Great.

However, the question of comparability of Russian and European texts is complicated by the emergence of competing narratives for Western Europe and Russia during the nineteenth century. While Gabriele Jancke has critiqued the concept of the individual in relation to Western European sources, in many nineteenth-century Russian texts, and all the more so in later Soviet discourse, such a liberal account of the self has long been the subject of criticism. ${ }^{5}$ In a reaction to Soviet censorship in the post-Soviet period there has been a boom in the writing and publication of self-narratives that document a sense of the uniqueness of the individual. ${ }^{6}$ Yet such a privileging of the individual should not be applied retrospectively to sources from the eighteenth century. In line with the work of colleagues in Berlin, Dr. Karpenko explained the need to reconstruct the context in which autobiographical texts were written and provide a clear answer to the question as to the aim(s) of a specific author.

In a follow-up paper that closed the panel session, Yury Zaretskiy outlined his research into the writing of "file-autobiographies". Professor Zaretskiy described the protocol that the authors of file-autobiographies followed in writing their accounts "in a free form", which led to the composition on the whole of dry, standard texts. However, it was argued that in presenting themselves to the authorities in a particular way authors made individual decision choices in recounting the life story.

The one big minus of the conference was the lack of participants from abroad. T.A. Saburova was the only scholar who reported on research on autobiography in Russia being conducted outside of Russia. It was therefore especially unfortunate that one of the co-editors of the journal AvtobiografiЯ Andrea Gullotta of Glasgow University was not able to give 
his panel paper on the study of Russian autobiography in the West. For example, the need for more awareness about work that has been done in the West was identified in the section on methodological issues, which considered the problem of interdisciplinary approaches in autobiography. ${ }^{7}$

Other sessions explored literary, religious and philosophical autobiography, respectively, the retrieval of texts from the archives, and the use of autobiography as sources in historical research and as evidence in legal cases. Subjects ranged from children and the aged, from people with disabilities to scholars and military figures, and gender issues were also addressed in papers on the voices of women and the portrayal of fatherhood. The chronological timeframe extended from the ancient world in Daniel Dorofeev's account of the study of autobiographical consciousness using texts from antiquity, to late medieval England, Germany and France, and the present day. It is thus important to stress that participants did not only look at autobiography in Russia, but contributed to the reception and study in Russia of autobiographical texts from other countries. The geographical diversity of autobiographical texts studied in Russia clearly facilitates a transnational perspective to the study of Russian texts.

In summary, in providing a balance sheet it is possible to refer back to autumn 2013, when the HSE research group on autobiography organised a small-scale conference where scholars from Moscow presented their work. ${ }^{8}$ Nearly three years later we managed to bring together specialists from a diverse range of backgrounds from across Russia. The main result is that scholars in the field of autobiography have a much clearer idea of what colleagues elsewhere in Russia are exploring across a range of periods, genres and countries. And thanks to generous coffee breaks and a buffet supper at the end of the first day, we helped promote discussions about future collaboration that will take forward the study of autobiography in Russia. To this end, a Russian-language publication of conference papers is in the pipeline in addition to the publication of the Russian translation of Rudolf Dekker's paper, as well as those of Elena Karpenko and Yury Zaretskiy in the anthropological journal of the Russian Academy of Sciences entitled "Chelovek".

\section{ABOUT THE AUTHOR}

The author is currently an independent scholar living in Moscow where he is involved with the HSE study group on autobiography. His recent article on Nikolai Chernyshevsky's use of a journalistic autobiographical pact appeared in the recent HSE publication Avtobiograficheskie svidetel'stva: perspectivy mezhdistsiplinarnikh issledovanii (Saint Petersburg: Aleteiia Press, 2016). News about the next conference on 1-2 June 2017 in Moscow can be found at https://phil.hse.ru/ en/autobio/announcements/202514551.html. 


\section{NOTES}

1 This review was prepared within the framework of the Academic Fund Program at the National Research University Higher School of Economics (HSE) in 2016-2017 (grant No. 16-05-0001) and supported within the framework of a subsidy granted to the HSE by the Government of the Russian Federation for the implementation of the Global Competitiveness Program.

2 Dr Dekker's paper drew upon an article he recently co-authored with Michael Mascuch and Arianne Baggerman, the other editors of the "Egodocuments in History Series," "Egodocuments and History: A Short Account of the Longue Durée," The Historian, 78, 2016, 11-56.

3 Istoria doreveliutsionnoi Rossii v dnevnikakh $i$ vospominaniakh (The pre-revolutionary history of Russia in diaries and memoirs), 5 vols., ed. P.A. Zaionchkovskii, Moscow, 1976-1985.

4 Jancke, Gabriele and Ulbrich, Claudia, "From the Individual to the Person: Challenging Autobiography Theory," in Mapping the "I": Research on Self-Narratives in Germany and Switzerland, eds. Claudia Ulbrich, Kaspar von Greyerz, Lorenz Heiligensetzer, (Brill: Leiden and Boston, 2015), pp. 15-33. For a review of "Mapping the "I"," see http://ejlw.eu/article/view/170.

5 For an influential recent re-statement in Russian of these debates, see Plotnikov, Vladimir. "Ot "Individual'nosti" $k$ "identichnosti" (istoriia poniatii personal'nosti v russkoi kul'ture)" (From "the individual" to "the personality" (The history of the concepts of personality in Russian Culture)), Novoe Literaturnoe Obozrenie, No. 91, 2008. This analysis was stimulated by the support of the research project "Person und Subjekt im deutsch-russischen Kulturtransfer. Untersuchungen zum Begriffsfeld der Personalität in interkultureller Perspektive."

6 For an overview of a selection of literary memoir texts, see Paperno, Irina, Stories of the Soviet Experience: Memoirs, Diaries, Dreams, (Ithaca: Cornell University Press, 2009). For a review of diary writing in the late Soviet period, see Pinsky, Anatolii "The Diaristic Form and Subjectivity under Khrushchev," Slavic Review, Vol. 73, No. 4 (Winter 2014), pp. 805-827.

7 For a discussion that combines literary and neurological perspectives on the question of trauma, see Paul John Eakin, Living Autobiographically: How We Create Identity in Narrative (Cornell University Press: Ithaca and London, 2008).

8 The conference resulted in the publication Avtobiograficheskie svidetel'stva: perspectivy mezhdistsiplinarnikh issledovanii (Autobiographical Testimonies: perspectives of cross-disciplinary research), Saint Petersburg: Aleteiia Press, 2016. 